Милош М. КОВАЧЕВИЋ* Филолошки факултет у Београду Филолошко-уметнички факултет у Крагујевцу
Оригинални научни рад

Примљен: 16. 11. 2016.

\title{
ОПОЗИТНИ ГЕНИТИВ С ПРЕДЛОГОМ ПРОТИВ И СИНОНИМСКЕ ПАДЕЖНЕ КОНСТРУКЦИЈЕ
}

\begin{abstract}
У раду се даје структурно-функционална и структурно-семантичка анализа генитивних падежних синтагми са предлогом против, које имају опозитно значење, на основу употребе у спортскоме језику. Опозитно значење одређује се као реципрочна супротстављеност два индивидуална или групна учесника у неком надметању. Анализа треба да освијетли карактеристике двају основних структурно-функционалних типова опозитних синтагми: глаголске и именичке, при чему се оба типа синтагми посматрају у суодносу са свим конкурентним морфосинтаксичким моделима падежних синтагми не само са структурног и семантичког него и са нормативног аспекта.

Кључне ријечи: предлог против, опозитно значење, реципрочна супротстављеност, спортски језик, нормативност
\end{abstract}

\section{О опозитном значењу}

Опозитно је једно од основних значења генитивног предлога против, јер га као нужну семантичку компоненту подразумијевају сва значења овог предлога. Значење супротности или противности увијек је (са)присутно у конструкцијама с предлогом против, али се свако значење супротстављања и/или противности не изражава генитивном конструкцијом с предлогом против.

У овоме раду нећемо се бавити свим значењским типовима опозитних генитивних синтагми с предлогом против, него само онима који подразумијевају реципрочну супротстављеност као „одмјеравање снага” двају појединачних или тимских надметача (такмаца). У питању су само опозитне конструкције из спортског језика, које подразумијевају „одмјеравање снага”

${ }^{*}$ mkovacevic31@gmail.com

** Рад је урађен у оквиру пројекта 178014: Динамика структура савременог сриског језика, који финансира Министарство просвете, науке и технолошког развоја Републике Србије 
такмичара у некој од спортских дисциплина. Циљ рада је да се, на богатом корпусу из новинарског спортског језика, попишу и опишу сви структурни, функционални и семантички а нормативно (не)допуштени подтипови опозитних конструкција с предлогом против, и да се изврши њихово поређење са конкурентним блискозначним и/или синонимним падежним конструкцијама. Од свих конструкција најконкурентније су генитивне конструкције с предлогом против и инструменталне с предлогом $c(a)$, прије свега због диобе значења социјативности.

\section{Структурно-функционални типови опозитних синтагми}

На основу категоријалне припадности надређеног члана и синтаксичке функције подређеног члана падежне синтагме издвајају се два темељна структурно-функционална типа опозитних падежних синтагми: а) глаголске, и б) именичке (супстантивне) синтагме.

У глаголским синтагмама предлошко-падежна опозитна конструкција има функцију прилошке одредбе или неправог објекта, а у њен састав улази само један супарник именован супстантивном ријечју уз генитивни предлог против или пак који други конкурентни му предлог. Тог супарника именованог генитивом уз предлог против зваћемо сунадметач. Други супарник, кога ћемо звати надметач, по правилу је у позицији експлицираног или неексплицираног субјекта. Семантички посматрани надметач и сунадметач јесу заправо реченични агенс и коагенс (нпр. Боковић се бори против Надала; Партизан је тријумфовао против Звезде; Играмо против Хрватске и сл.).

У супстантивним синтагмама именица као надређени члан предодређује функцију атрибута, и то неконгруентног генитивној конструкцији с предлогом против, с тим да је тим неконгруентним атрибутом увијек именован сунадметач као коагенс. Надметач или агенс може бити у саставу супстантивне синтагме или изван њеног састава. Ако је саставни дио супстантивне синтагме, надметач или агенс такође је изражен неконгруентним атрибутом, али у генитивној беспредлошкој форми (нпр.: Утакмища Србије против Хрватске била је драматична). Супстантивна опозитна синтагма с предлогом против и са надметачом и са сунадемтачом у свом саставу има два неконгурентна атрибута: један беспредлошки генитивни којим се именује надметач као агенс, и други у форми генитива с предлогом против којим се именује сунадметач као коагенс. Осим у форми беспредлошког неконгруентног атрибута надметач у саставу супстантивне синтагме може бити изражен и формом конгруентног посесивног атрибута (као нпр.: Новаков дуел против Федерера дуго ће се препричавати). Све конкурентне супстантивне синтагме с надметачем и сунадметачем у свом саставу нису, како ћемо видјети, с наведеним синтагмама хомоформне у погледу падежне форме неконгруентних атрибута. Много је чешћи случај да се у оквиру опозитне супстантивне синтагме именује само један од супарника, и то сунадметач, генитивом именице уз предлог против, 
док други супарник - надметач - не улази у састав супстантивне синтагме него је или неексплициран па се контекстуално подразумијева, или је експлициран у позицији неког другог члана, најчешће субјекта (као нпр.: Меч против Америке био је тежак; Металаи је у сусрету против Звезде освојио бод).

\section{Глаголске синтагме с опозитним падежним конструкцијама}

Опозитно значење реципрочне супротстављености генитивних конструкција с предлогом против, а и неких конкурентних им предлошко-падежних конструкција, често се препознаје већ у семантици надређеног синтагматског члана: глагола или именице. Ту групу чине прије свега глаголи који се семантички могу одредити као опозитно сощијативни глаголи. А то су сви глаголи који подразумијевају учешће и надметача и сунадметача у спортском „одмјеравању снага”, какви су нпр.: борити се, такмичити се, ремизирати, састати се, тријумфовати, ратовати, атаковати, нападати, играти и сл., што потврђују и сљедећи корпусни примјери ${ }^{1}$ :

(1) Са друге стране белоруска екипа је на страни последњи пут тријумфовала пре три године против Лила. (Политика, 4. 11. 2015, 35); Фудбалери Партизана ... cy синоћ у Букурешту ремизирали против Стеауе. (Курир, 30. 7. 2015, 34); Најбољи тенисер света ... за финале се синоћ борио против Монфиса. (Политика, 31. 7. 2016, 32); Ремизирали смо на свом терену против Динама. (Вечерње новости, 17. 8. 2016, 34); Аргентина ће играти против Белгије. (Политика, 19. 7. 2015, 34); и сл.

Уз готово све те глаголе генитив с предлогом против замјењив је инструменталом с предлогом $c(a)$ као синонимом:

(1a) Новак Ђоковић експресно савладао Доминика Тима и сутра ће се са Марејом борити за пехар. (Вечерње новости, 4. 6. 2016, 48: наднаслов); Лудогорец ... је ремизирао са Плзењом у Чешкој. (Вечерње новости, 24. 8. 2016, 35); Пари Сен Жермен се само једном сусрео са Манчестер ситијем. (Вечерње новости, 19. 3. 2016, 47); Србија је у финалу Олимпијских игара у коме ће се сутра састати са Хрватском. (Политика, 19.8. 2016, 25); Ђоковић ће данас играти са Томамом Бердихом. (Политика, 8. 1. 2016, 32) и сл.

Тест супституције ових двију опозитних конструкција показује да се генитивна конструкција с предлогом против може замијенити инструменталном с предлогом $c(a)$ као синонимом, док обрнута замјена није увијек могућа. То даље значи да међу опозитно социјативним глаголима има оних који искључују генитивну а намећу као једино рјешење инструменталну конструкцију. Такви су, на примјер, глаголи сусрести се и састати се, код којих је захваљујући социјативном префиксу опозитно значење у сјенци социјативног.

Много су чешће ситагме с контекстуалним на значењу предлога против темељеним, а глаголом незадатим опозитним социјативним значењем. То су

\footnotetext{
${ }^{1}$ Сви примјери што их наводимо ексцерпирани су из спортског жанра новинског подстила публицистичког стила савременог српског књижевног (стандардног) језика. Попис извора дат је на крају рада.
} 
синтагме с несоцијативним глаголима у предикату који не предодређују али и не спречавају реализацију опозитне генитивне конструкције с предлогом против, што потврђује сљедећих неколико примјера (који су у корпусу врло бројни):

(2) Против Малека сам доста грешио. (Вечерње новости, 25. 2. 2016, 37); ...jep hе против Стеауе за два дана на терен истрчати потпуно други тим. (Вечерње новости, 3 . 8. 2015, 38); Војводина славила против шалпиона (Политика, 8. 5. 2016, 35: наслов); У нашој групи су све екипе веома опасне, против Велса и Ирске мораћемо физички добро да парирамо. (Политика, 27. 7. 2015, 32); Одлично је бранио Гојко Пијетловић против Мађаpa. (Политика, 8. 8. 2016, 22); Чуо сам да нас је њихов тренер Валтер Зенга посматрао против Чукаричког у првенству. (Политика, 1. 8. 2015, 32); Мучили су се Звездини фудбалери против Валете. (Политика, 21. 7. 2016, 31); Звезда је против Радничког имала пенал. (Вечерње новости, 22. 5. 2016, 40); Мадриђани воде против Римљана са 5:3 у тријумфима. (Вечерње новости, 8. 3. 2016, 37); Милица креће у одбрану злата против Норвежанке (Блиц, 20. 8. 2016, 35: наслов); и сл.

У овом типу синтагми управни глагол не садржи компоненту опозитне социјативности. То значење предлог против добија у контекстима у којима присуство реципрочно супротстављеног надметача и сунадметача намеће значење „одмјеравања снага”. Сви се наведени примјери могу, међутим, сматрати „компримирано” елиптираним, јер се у свима њима испред генитивне конструкције с предлогом против може експлицирати нека именица са значењем надметања, типа: утакмица, меч, дуел и сл., као нпр.: Звезда је против Радничког имала пенал $\rightarrow$ Звезда је НА УТАКМИЦИ/МЕЧУ против Радничког имала пенал; Одлично је бранио Гојко Пијетловић против Мађа$p a \rightarrow$ Одлично је бранио Гојко Пијетловић НА УТАКМИЦИ/МЕЧУ против Мађара; Мучили су се Звездини фудбалери НА УТАКМИЦИ/МЕЧУ против Валете $\rightarrow$ Мучили су се Звездини фудбалери против Валете; Чуо сам да нас је њихов тренер Валтер Зенга посматрао против Чукаричког у првенству $\rightarrow$ Чуо сам да нас је њихов тренер Валтер Зенга посматрао НА УТАКМИЦИ/ МЕЧУ против Чукаричког у првенству; Мадриђани воде против Римљана са 5:3 у тријумфима $\rightarrow$ Мадриђани воде У СУСРЕТИМА/МЕЧЕВИМА против Римљана са 5:3 у тријумфима; Милица креће у одбрану злата против Норвежанке $\rightarrow$ Милица креће у одбрану злата ДУЕЛОМ/МЕЧОМ против Норвежанке и сл. Експлицирањем елидиране именице са значењем надметања синтагма мијења свој структурни статус, а генитивна конструкција своју синтаксичку функцију: то више није глаголска синтагма са прилошкоодредбеном функцијом генитива с предлогом против, него супстантивна синтагма у којој је генитив с предлогом против неконгруентни атрибут.

\section{Супстантивне синтагме с опозитним падежним конструкцијама}

За разлику од глаголских синтагми, семеме свих именица у позицији надређеног члана опозитних генитивних синтагми с предлогом против подразумијевају присуство семантичке компоненте опозитне социјативности. А 
управо су то именице које се као елиптиране могу реконструисати у примјерима глаголских синтагми с управним несоцијативним глаголом. Ако је судити према корпусу, то су, не тако бројне, сљедеће именице са општим значењем „надметања”: двобој, борба, битка, рат, окршај, дуел, меч, двомеч, надметање, утакмица, сусрет, судар, дерби, финале, полуфинале, четвртфинале, реми, реванш:

(3) Карте за реванш меч против Стеауе пуштене су у продају. (Блиц, 3. 8. 2015, 36); Због проблема са повредом капитен је синоћ пропустио контролну утакмииу са Мађарском. (Вечерње новости, 3. 8. 2015, 37); Он је затим додао шта очекује на сусрету против Велса. (Политика, 1. 7. 2016, 35); Ћорић изборио дуел против Ђоковића (Вечерње новости, 4. 5. 2016, 32: наслов); У окршај против Италијанки на Европском првенству у Београду наше ватерполисткиње су ушле без нереалних очекивања. (Политика, 18. 1. 2016, 31); Шансу ... су искористили лане у финалу против финских Петлова. (Политика, 27. 7. 2015, 29); Чињеница је да смо у реваншу против Стеауе имали невероватну подршку трибина. (Политика, 8. 8. 2015, 32); У двобој против Сампдорије Војводина је ушла са шест такмичарских утакмица иза себе. (Политика, 1. 8. 2015, 31); Дакле, пред нама је најмање још 90 минута велике борбе против ривала који нам није дао гол из игре, него из прекида. (Вечерње новости, 19. 8. 2015, 40); и сл.

Уз све наведене именице опозитни генитив с предлогом против у функцији неконгруентног атрибута замјењив је социјативним инструменталом с предлогом $c(a)$ као синонимом, што потврђује и велики број у корпусу забиљежених примјера:

(3а) Двомеч са Стеауом је у хероја промовисао Андрију Живковића. (Вечерње новости, 25. 8. 2015, 38); Није било страха пред дуел са Црном Гором. (Политика, 28. 7. 2015, 36); Наш сусрет са Кастриотијем, то је ваљда свима јасно, није само спортски догађај. (Политика, 23. 7. 2015, 35); Меч са Звездом је одигран у духу фер-плеја. (Вечерње новости, 31. 7. 2015, 39); Што се тиче утакмище са Јапаном, неизвесност је била само у првој четвртини. (Курир, 30. 7. 2015, 39); Партизан ће у реваншу са Стеауом имати прилику да стигне на корак до пласмана у европску елиту. (Политика, 3. 8. 2015, 31); Наравно да ниједна неће поменути већ виђени окршај са Аустралијом. (Политика, 14. 8. 2016, 22);...најближа будућност је евролигашки судар са моћном руском Локомотивом у „Пиониру”. (Вечерње новости, 27. 1. 2016, 38); ...али су на игри црвено-белих у првом полувремену били јасно уочљиви ожиљци из евролигашке битке са Панатинаикосом. (Вечерње новости, 16. 2. 2016, 40); „Црвено-белим” предстоји велика борба са Бајерном и Стразбуром. (Политика, 15. 10. 2015, 32); и сл.

Уочљиво је да се опозитни генитив с предлогом против и опозитни инструментал с предлогом $c(a)$ јављају као синоними и уз именицу сусрет (нпр. Сусрет против Велса / сусрет са Велсом био је тежак), иако је уз глагол сусретати се могућа само инструментална форма (уп.: Сусрели смо се са Велсом, али не: * Сусрели смо се против Велса). Уз то, према глаголској синтагми с глаголом састати се нема супстантивне синтагме с именицом састанак (уп.: Састали смо се са Велсом јесенас, али не: *Састанак с Велсом био је јесенас).

Уз све наведене именице (борба, битка, рат, окриај, дуел, двобој, меч, двомеч, надметање, утакмица, сусрет, судар, дерби, финале, полуфинале, четвртфинале, реми, реванш) као значењски конкуренти генитивној и инструменталној супстантивној синтагми јављају се још три структурна типа 
супстантивних опозитних синтагми, које за структурну инваријанту имају координирани однос именица којима се обиљежавају надметач и сунадметач, односно агенс и коагенс. Структура тих трију типова супстантивних синтагми је сљедећа: 1) супстантивна синтагма с координацијом двају неконгруентних атрибута у форми беспредлошког генитива, 2) супстантивна синтагма с координацијом двају неконгруентних атрибута у форми генитива с предлогом између, и 3) супстантивна синтагма с невезничком, примакнутом цртом обиљеженом, координацијом именица којима се именују надметачи у односу на које именица са значењем надметања има функцију атрибутива. У питању су, дакле, три међусобно замјењиве и у основи синонимне супстантивне синтагме, с тим да у двјема подређени члан представљају координирани неконгруентни атрибути, а у трећој координирани чланови су надређени члан синтагме уз који у функцији атрибутива долази именица са значењем двобоја (нпр.: Меч Србије и Америке био је драматичан; Меч између Србије и Америке био је драматичан; Меч Србија-Америка био је драматичан).

Уз наведене именице са значењем надметања могу се употријебити два везником $u$ повезана неконгруентна атрибута, којима се хијерархијски и семантички изједначују оба члана опозитног односа - и надметач као агенс и сунадметач као коагенс. Ово је врло фреквентан тип супстантивне опозитне синтагме, за чију потврду наводимо само неколико забиљежених примјера из спортског језика:

(3б) Као по неписаном правилу, утакмице Србије и Аустралије су пуне преокрета. (Политика, 1. 8. 2015, 30); Уочи меча Сутјеске и Партизана подигла се велика тензија. (Вечерње новости, 4. 1. 2016, 36); Свет је две године чекао дуел Усеина Болта и Џестина Гетлина. (Вечерње новости, 27. 8. 2015, 37); Било је и других неочекиваних утакмица попут ремија Кине и Бразила (Политика, 2. 8. 2015, 33); Борба Партизана и Звезде за преимућство (Политика, 12. 4. 2016, 39: наслов); Данашњи дуел је седми окршај Суботичана u ,ирно-белих" у најмасовнијем такмичењу. (Политика, 20. 4. 2016, 40); Судбински сусрет Хрватске и Србије донеће одличан меч. (Данас, 17. 8. 2016, 24) и сл.

Наведена форма опозитне беспредлошке генитивне синтагме има свој пандан у употребно чешћој опозитној генитивној синтагми у којој уз именице са значењем двобоја долазе два генитивом с предлогом између изражена неконгруентна атрибута међусобно координирана везником $u$ :

(3в) Утакмица између ОФК Београда и Црвене звезде изазвала је неуобичајено велику пажњу јавности. (Политика, 21. 7. 2015, 32); Вимблдонски меч између Федерера и Ђоковића гледао је на реци. (Блиц, 31. 7. 2015, 10); Колико су наши фудбалски тренери били цењени у иностранству, могло се видети у недавном двомечу између Војводине и Сампдоpuје у квалификацијама за Лигу Европе. (Политика, 23. 8. 2015, 33); Други дан викенда у енглеској Премијер лиги обележио је дерби сусрет између Манчестер ситија и Челзија. (Политика, 17. 8. 2015, 31); Данашњи дуел између Јавора и Радника ... могао би много тога да реши. (Политика, 12. 3. 2016, 31); У надметање између тренутно првог и другог рекета света може да се умеша Хуан Мартин дел Потро. (Данас, 26. 8. 2016, 26); и сл.

Трећи се структурни тип супстантивних синтагми од два претходна структурно најприје разликује по обрнутој перспективизацији надређеног и подређеног члана опозитне супстантивне синтагме, али и по начину координације именица којима се обиљежавају супарници. Наиме, супарници 
- надметач и сунадметач - писани су готово полусложенички. Везник $u$ из независне саставне конструкције сада је замијењен много чешће примакнутом иртом него одмакнутом. Именице повезане примакнутом цртом у номинативној су форми, па се тако обиљежен двопојам доима као јединствена цјелина, која је сад, по у србистици општеприхваћеном мишљењу, надређени члан претходећој јој именици, у овом случају именици са општим значењем двобоја у функцији атрибутива ${ }^{2}$ :

(Зг) УЕФА му је поверила да дели правду на утакмици Шпанија-Турска. (Вечерње новости, 15. 6. 2016, 38); Сусрет Раднички-Партизан добио је карактер утакмице високог ризика. (Политика, 6. 3. 2016, 35); Александар Атанасијевић је у Перуђи ... гледао финале Србија-Бразил. (Вечерње новости, 19. 7. 2016, 40); Фудбалски меч Србија-Русија у Монаку (Политика, 13. 4. 2016, 35: наслов); Дуел Федерер-Надал је био све у тенису. (Политика, 18. 6. 2016, 30); Милорад Мажић је успешно положио пре две ноћи испит на мечу Ирска-Шведска. (Вечерње новости, 15. 6. 2016, 38); и сл.

Супстантивне опозитне синтагме често за управни члан имају различите девербативне (глаголске) именице. У питању су супстантивне синтагме настале у процесу номинализације глаголских синтагми, прије свега оних опозитно социјативних генитивних и инструменталних. При том су зависни чланови захваљујући глаголској именици у надређеном члану своју прилошкоодредбену функцију из глаголске синтагме преобразили у функцију неконгруентног атрибута у супстантивној (в. Ковачевић 1992:23). Овим типом номинализације настао је велики број супстантивних и генитивних и инструменталних опозитних синтагми, као нпр.:

(4) Игра против Порторика [Ł играти против Порторика] била је за класу боља. (Политика, 10. 7. 2016, 36); Нови Пазар је у овој (сезони) стартовао поразом на свом терену од Јавора и ремијем против Младости [ $\leftarrow$ ремизирати против Младости] у Лучанима. (Политика, 1. 8. 2015, 31); Дакле, пред нама је најмање још 90 минута велике борбе против ривала $[\leftarrow$ борити се против ривала] који нам није дао гол из игре, него из прекида. (Вечерње новости, 19. 8. 2015, 40); и сл.

Глаголска и супстантивна синтагма у оваквим примјерима имају изоморфну структуру зависног члана: уз глаголску именицу зависни члан задржава падежну форму коју је имао уз глагол. Од тога правила при номинализацији глаголских синтагми постоје два изузетка: 1) у номинализованој синтагми јавља се алтернативна падежна форма зависног члана неостварива у глаголској синтагми, и б) номинализована структура има потпуно неподударну форму зависног члана у односу на глаголску.

Први случај подразумијева постојање двију зависних падежних форми од којих је само једна хомоформна оној из глаголске синтагме. Такав је случај са супстантивним синтагмама с глаголским именицама сусрет и тријумф у надређеном члану. Уз падежну форму коју „насљеђују” из глаголске синтаг-

\footnotetext{
${ }^{2}$ Атрибутиви се одређују као препозицијске именице „које такође стоје уз друге именице и врше службу њихова одређивања, али не означавају исти него шири појам, појам врсте или рода коме главни појам припада", као нпр.: варошица Прњавор, река Зета, село Бистрица, цар Стјепан и сл. (Стевановић 1988: 106). Иако општеприхваћено у србистици, чини ми се да је противно логици да унутар једне синтагме шири члан одређује ужи, а не обрнуто.
} 
ме - а то је инструментал с предлогом са уз глагол сусретати се, а генитив с предлогом против уз глагол тријумфовати - те именице добијају и алтернативне падежне форме зависног члана неоствариве у глаголској синтагми, и то именица cycpem генитив с предлогом против, а именица тријумф форму инструментала с предлогом над, чему су потврда и сљедећи забиљежени примјери:

(4a) Јуче је Азаведо у неважном сусрету с Италијом [ $\leftarrow$ сусрести се са Италијом] последњи пут водио свој тим. (Политика, 15. 8. 2016, 21); Он је затим додао шта очекује на сусрету против Велса $\left[\leftarrow{ }^{*}\right.$ сусрести се против Велса] (Политика, 1. 7. 2016, 35); Тренер нашег шампиона ... након великог тријумфа против Румуна $[\leftarrow$ тријумфовати против Румуна] није крио емоције. (Политика, 8. 8. 2015, 32); Маестралан тријумф Војводине над Сампдоријом [ $\leftarrow$ *тријумфовати над Сампдоријом $\left.{ }^{3}\right]$ свакако заслужује да се нађе у аналима нашег спорта. (Курир, 1. 8. 2015, 35) и сл.

Други случај односи се на потпуну неизоморфност зависног члана глаголске и номинализоване синтагме, што значи да се форма зависног члана глаголске синтагме не реализује у оквиру номинализоване супстантивне синтагме. Такве су, на примјер, номинализоване синтагме с глаголским именицама побједа и реванш. Специфичност супстантивних синтагми с овим именицама у односу на претходне (4 / 4a) добијене номинализацијом огледа се прије свега у структурно-функционалном типу номинализацији подвргнутих глаголских синтагми. У питању нису глаголске прилошкоодредбене предлошко-падежне синтагме, какве су све претходне (4/4a), него глаголске објекатске беспредлошке синтагме. Глагол реванширати твори само беспредлошку дативну синтагму: реванширати се коме, док глагол побиједити твори искључиво акузативну синтагму правог објекта: побиједити кога. При номинализацији синтагме с глаголом реванширати се претворбом глагола у именицу реванш зависни члан синтагме не остаје беспредлошки датив јер он не твори слободну супстантивну синтагму ${ }^{4}$, него се умјесто датива употребљава или генитив с предлогом против или инструментал с предлогом $c a$ (нпр. реванш против Партизана / реванш са Партизаном). Што се пак синтагми правог објекта тиче, под које потпада и синтагма с глаголом побиједи$m u$, при номинализацији прави објекат „постајући неконгруентни атрибут по правилу прелази у форму беспредлошког (тзв. објекатског) генитива (нпр.: читање књиге, кречење собе, одбрана града). Ту форму неконгруентни атрибут настао од беспредлошког акузативног објекта не добија једино у оним случајевима када би се као примарно наметало субјекатско а не објекатско значење неконгруентног атрибута" (Ковачевић 1992: 22-23), а управо је то случај са номинализацијом објекатске синтагме с глаголом побиједити, у којој се уз именицу побједа акузативна беспредлошка форма не преобра-

\footnotetext{
${ }^{3}$ Истина, оказионално ће се сусрести и хомоформна глаголска синтагма, што потврђује и једини забиљежени примјер из нашег врло обимног корпуса: Било би дивно да је наш представник тријумфовао над италијанским зато што је стварно бољи. (Политика, 1. 8. 2015, 31).

${ }^{4}$ То значи да је номинализацијом добијена синтагма реванш коме дистрибуционо условљена типом предиката реченице, тако да нпр. није овјерена реченица * Ревани Звезди неће бити лак, али је овјерена: С нестрпљењем ишчекујемо ревани Звезди.
} 
зује из значењских разлога у генитивну ${ }^{5}$, него у генитивну форму с предлогом против или у инструменталну с предлогом над, као нпр.:

(4б) Жеља је испуњена - победом против Црне Горе [Łпобедити Црну Гору, али не: *nобедити против Црне Горе] Србија је направила велики корак ка освајању првог места у групи. (Политика, 29. 7. 2015, 30); Победа над Црном Гором [Łпобедити Црну Гору, али не: *победити над Црном Гором] није пресудна. (Вечерње новости, 29. 7. 2015, 37); Реванш против Сасуола [ $\leftarrow$ реванширати се Сасуолу, али не: *реванширати се против Сасуола] могао би да буде последњи меч Александра Катаија у дресу Звезде. (Блиц, 20. 8. 2016, 31); Да ли ће европска сезона за фудбалере Црвене звезде бити завршена сутра ... биће познато након реванша са Сасуолом [ $\leftarrow$ реванширати се Сасуолу, али не: *реванширати се са Сасуолом] (Политика, 24. 8. 2016, 23) итд.

Велики број опозитних супстантивних синтагми настаје у процесу номинализације глаголских опозитних синтагми. Глаголска именица добијена номинализацијом, међутим, не мора бити искључиво дио супстантивне неконгруентне опозитне синтагме, него може ући и у састав перифрастичког предиката, као нпр.: Забележили су победу против Звезде [ Звезду].

\section{Нормативни статус опозитних падежних конструкција}

Готово да нема нормативног приручника у коме се као ненормативни не помињу одређени, праксом потврђени, структурни типови опозитних падежних конструкција. Тако се унисоно, чак уз поткрепу двама истим примјерима, осуђује „злоупотреба” предлога против „у језику спортских новинара” уз глаголе побиједити и изгубити: „Победићемо против Звезде, Изгубили су против Франиуза и сл., уместо: Победићемо Звезду, Изгубили су од Франиуза и сл.” (Клајн 1992: 136; Пипер/Клајн 2013: 385; Николић 2015: 13; Стијовић 2015: 7).

У корпусу смо забиљежили немали број примјера употребе предлога против у синтагмама с глаголом (из)губити и уз именицу пораз:

(6) Нејасно ми је како на Гуглу има само његових мечева у којима је губио против [ $\rightarrow$ од] слабијих противника. (Политика, 24. 1. 2016, 34); У групној фази против [ $\rightarrow$ од] Сједињених Америчких Држава сте изгубили само три поена разлике. (Политика, 21.8. 2016, 28); Из пораза против [ $\rightarrow$ од] Роцера, као и сваког претходног, покушаћу да извучем поуке. (Политика, 19. 11. 2015, 36); Пораз Милана на гостовању против [ $\rightarrow$ од] Сасуола био је довољан за нову лавину нагађања италијанских спортских медија. (Вечерње новости, 9. 3. 2016, 39); и сл.

Неспорно је да је глаголу (из)губити и именици пораз рекцијска допуна генитив с предлогом од, а не генитив с предлогом против. Томе је разлог

\footnotetext{
5 Таква номинализација довела би до „погрешног” значења, тако да нпр. номинализована синтагма побједа Звезде према глаголској побиједити Звезду има антонимско значење: у номинализованој синтагми Звезда се ишчитава као побједник (јер побједа Звезде значи Звезда је побиједила), док се у глаголској синтагми Звезда ишчитава као поражени тим (јер побиједити Звезду значи Звезда је поражена).
} 
прије свега чињеница што се уз те лексеме генитивном допуном именује агенс пасивне конструкције, који се у српском језику изражава готово искључиво формом од (стране) + генитив (уп. Танасић 2005: 157). Из тих разлога и нема нормативног оправдања употреби генитива с предлогом против у датим конструкцијама. ${ }^{6}$

Још један се нормативни проблем јавља у вези са (не)синонимношћу конструкција с инструменталним предлогом $c(a)$ и генитивним предлогом против. У конструкцијама с појединим глаголима - какви су нпр.: борити ce, ратовати, играти - у спортском језику употреба предлога са доводи до бисемичности реченице, јер се не зна да ли је у питању социјативно значење „заједничког дјеловања” или пак значење „реципрочне супротстављености”, као нпр. у сљедећа неколика примјера из нашег корпуса:

(7) Све док не будем морао да играм са њим, нећу мислити о њему. (Политика, 17. 1. 2016, 33); Нисам играо са Новаком, али сам често тренирао са њим. (Политика, 24. 2. 2016, 34); ...али када сам са Крајиновићем играо у Мајамију прошле године, били смо обојица веома стегнути. (Политика, 24. 5. 2016, 32) и сл.

У наведеним и сродним примјерима није јасно да ли се инструменталном конструкцијом обиљежава социјативно значење „заједничког дјеловања": Све док не будем морао да играм са юим ...= Све док не будем морао да играм ЗАЛЕДНО са юим... - или пак опозитно значење ,реципрочног супротстављања": Све док не будем морао да играм са юим ...=Све док не будем морао да играм ПРОТИВ њега... Овакав тип бисемичности у опозитним конструкцијама треба „избегавати употребом генитива с предлогом против (Борили су се против Немаца) за реципрочну супротстављеност, посебно ако контекст није довољан да отклони могућу двосмисленост" (Пипер/Клајн 2013: 385).

\section{Закључак}

Анализа опозитних генитивних синтагми с предлогом против са значењем реципрочне супротстављености укључивала је и анализу конкурентних падежних синтагми у изражавању опозитног значења, прије свега оне најконкурентније, а то је инструментална синтагма с предлогом $c(a)$. Све смо опозитне синтагме у овом раду подијелили на глаголске и именичке.

Глаголске опозитне синтагме разврстане су у двије групе на основу тога да ли је опозитно значење задато опозитно социјативном семантиком управног глагола (какви су нпр. глаголи: борити се, такмичити се, ремизирати, састати се, тријумфовати, ратовати, атаковати, нападати, играти), или је опозитна семантика контекстуално задата а ослоњена на значење предлога

\footnotetext{
${ }^{6}$ У посебном рад(ић)у (Ковачевић 2016а: 13) освијетлили смо разлоге ненормативности ових конструкција.
} 
против подржано експлицитно или имплицитно присутним надметачем и сунадметачем.

И опозитне супстантивне синтагме чине два структурно-семантичка типа, али на основу друкчијег критеријума. Први тип чине супстантивне синтагме настале номинализацијом глаголских (нпр.: играње против Америке/са Америком). Други тип чине структурно разнородније синтагме, чије управне именице подразумијевају присуство семантичке компоненте опозитне социјативности, а то су именице са општим значењем „надметања”: двобој, борба, битка, рат, окршај, дуел, меч, двомеч, надметање, утакмица, сусрет, судар, дерби, финале, полуфинале, четвртфинале, реми, реванш. Опозитном супстантивном моделу с генитивом с предлогом против као неконгруентним атрибутом, синониман је инструментални модел с предлогом са (уп. меч/утакмииза Србије против Америке/са Америком). А тим двама моделима конкуришу још три модела опозитних супстантивних синтагми: 1) супстантивна синтагма с координацијом двају неконгруентних атрибута у форми беспредлошког генитива (нпр.: меч Србије и Америке), 2) супстантивна синтагма с координацијом двају неконгруентних атрибута у форми генитива с предлогом између (нпр.: меч/утакмица између Србије и Америке), и 3) супстантивна синтагма с невезничком, примакнутом цртом обиљеженом координацијом именица у односу на које именица са значењем надметања има функцију атрибутива (нпр.: меч/утакмица Србија-Америка).

У оквиру опозитних генитивних конструкција с предлогом против нормативно су најспорније конструкције с глаголима изгубити и побиједити и именицом пораз у позицији надређеног синтагматског члана. Неколика структурно-семантичка разлога не оправдавају употребу генитива с приједлогом против уз те три лексеме (као нпр.: *Пораз против Русије био је болан; *Победили су против Русије; *Изгубили су против Русије) без обзира на њихову фреквентност у језику спортских новинара.

\section{ИЗВОРИ}

Блиц - Blic, dnevne novine iz Beograda.

Вечерње новости - Вечерње новости, дневне новине из Београда.

Данас - Danas, dnevne novine iz Beograda.

Курир - Kurir, dnevne novine iz Beograda.

Политика - Политика, дневне новине из Београда.

\section{ЛИТЕРАТУРА}

Клајн 1992: I. Klajn, Rečnik jezičkih nedoumica, Beograd: Nolit.

Ковачевић 1992: M. Kovačević, „Semantički tipovi nekongruentnih atributa”, y: Kroz sintagme i rečenice, Sarajevo: Svjetlost, 9-29. 
Ковачевић 2016: М. Ковачевић, „Реченице с конверзијом прилошке адвербијалне допуне или одредбе и придјевског атрибута", у: Jezik, književnost, značenje: jezička istraživanja, urednice B. Mišić Ilić, V. Lopičić, Niš: Filozofski fakultet, 389-408.

Ковачевић 2016а: М. Ковачевић, „Победити и поразити нису што и победа и пораз”, Политика, 9. 11. 2016, 13.

Николић 2015: М. Николић, „Било је за неверовати”, Политика, 8. 9. 2015, 13.

Пипер и др. 2005: П. Пипер и др., Синтакса савременога српског језика: проста реченица, ред. М. Ивић, Београд: Институт за српски језик САНУ, Београдска књига; Нови Сад: Матица српска.

Пипер/Клајн 2013: П. Пипер, И. Клајн, Нормативна граматика српског језика, Нови Сад: Матица српска.

Стевановић 1988: М. Стевановић, „Карактер одредаба самосталних речи и разлике међу њима", у: Студије и расправе о језику, Никшић: Универзитетска ријеч, 98-109.

Стијовић 2015: Р. Стијовић, „Гостовати некоме”, Политика, 26. 9. 2015, КУН, 7.

Танасић 2005: С. Танасић, Синтаксичке теме, Београд: Београдска књига.

Фелешко 1995: К. Фелешко, Значења и синтакса српскохрватског генитива, Београд: Вукова задужбина; Нови Сад: Матица српска, Орфелин, $149-151$.

Miloš Kovačević

OPPOSITIONAL GENITIVE WITH THE PREPOSITION PROTIV AND SYNONYMOUS CASE CONSTRUCTIONS

Summary

The paper provides a detailed structural-functional and structural-semantic analysis of the genitive case phrases containing the preposition protiv (Eng. against), which convey the meaning of oppositeness. Oppositional meaning is defined as the reciprocal confrontation of two individual participants or group of participants in a competition. Using a large corpus of journalistic sports language, all the structural, functional and semantic normatively (dis)allowed subtypes of opposite constructions containing the preposition protiv have been listed and described, including their comparison with competing case constructions which have similar meaning and/or are synonymous to them. By all criteria of the analysis, the greatest concordance, almost synonymy, has been found in genitive constructions with the preposition protiv and the instrumental constructions with the preposition $s$ (a) (Eng. with), primarily because they share the sociative meaning, and it has further been shown that not all sociativity, even the reciprocal one, represents opposition. Repartition of other competing case forms depends initially on which of the two functional types of oppositional phrases we have in mind, i.e. whether they are verb phrases or substantive phrases, noting that the model synonymy is greater within the substantive phrase.

The analysis has shown that the genitive with the preposition protiv within the oppositional verb phrase performs the function of an adverbial modifier or complement of contrast, more precisely a contrasting adverbial modifier or complement.

Within the group of oppositional genitive constructions with the preposition protiv, the most normatively problematic structures are the ones containing the verbs izgubiti (Eng. lose) and pobijediti (Eng. win) and the noun poraz (Eng. defeat). Structural-semantic reasons have been provided to ex- 
plain the lack of justification concerning the use of the oppositional genitive phrases with the preposition protiv with these three lexemes (e.g.: *Poraz protiv Rusije bio je bolan. (Eng. Defeat against Russia was painful); *Pobedili su protiv Rusije. (Eng. They won against Russia); *Izgubili su protiv Rusije (Eng. They lost against Russia)), regardless of their frequency in the language use of sports journalists. 